NBER WORKING PAPER SERIFS

THE ILLUSTON OF

STABILIZATION POLICY?

Steven L. Green

Herschel I. Grossman

Working Paper No. 1889

NATIONAL BUREAU OF ECONOMIC RESEARCH

1050 Massachusetts Avenue

Cambridge, MA 02138

Apr $† 11985$

Revised version of a paper presented at the Camegie-Rochester conference on Public Policy, Pittsburgh, November 22-23, 1985. National Science Foundation Grant SES-8408373 has supported this research. Ray Lombra and other conference participants made helpful comments on an earlier draft of this paper. Jeffrey Gunther provided valuable research assistance. The research reported here is part of the NBER's research programs in Economic Fluctuations end Financial Markets and Monetary Economics. Any opinions expressed are those of the authors and not those of the Nationat Bureau of Economic Research. 
NBER Working Paper \#1889

April 1986

The Illusion of Stabilization Policy?

$\underline{\text { ABSTRACT }}$

For the period 1959-1972 money growth in the United States was positively correlated with past inflation and negatively correlated with past unemployment, whereas for the period 19731984 this correlation pattern was reversed. International data, moreover, show that the eight largest western economies exhibit a wide variety of patterns for these correlations, and these patterns seem to be unrelated to average inflation. Theoretical analysis reveals that a model in which the monetary authority is concerned only with controlling inflation is consistent with any pattern of sample correlations of money growth with past

inflation and past unemployment. This analysis suggests that international differences in these sample correlations result from differences in the sample variances of disturbances to productivity growth and to aggregate demand. Specifically, the analysis suggests that the critical difference between the pre1973 and post-1973 periods for the United States was a decrease in the importance of transitory disturbances to aggregate demand relative to permanent disturbances to productivity growth. More generally, these results imply that we cannot readily infer the objectives of the monetary authority from observed patterns of monetary policy.

Steven Green

Research Department

Federal Reserve Bank of Dallas

Dallas, TX 75222
Herschel Grossman

Department of Economics

Brown University

Providence, RI 02912 
1. Inflation and Patterns of Money Growth

For the period 1959-1972 money growth in the United States was positively correlated with past inflation and negatively correlated with past unemployment, whereas for the period 19731984 this correlation pattern was reversed. Moreover, as summarized in the table, international data show that the eight largest western economics exhibit a wide variety of patterns for these correlations. This paper develops a positive theoretical model of monetary policy that shows that intertemporal and international differences in these sample correlations can result from differences in the sample variances of disturbances to productivity growth and to aggregate demand. The distinctive feature of this model is the assumption that monetary authorities behave as if their sole objective was the achievement of a given target path for inflation.

This parsimonious theoretical specification of the objectives of monetary policy contrasts sharply with theories that attribute observed patterns of monetary growth to alleged stabilization objectives. In a widely accepted example of such an analysis, John Taylor (1981, 1982) characterizes monetary policy in the United States as excessively accommodative of inflation, and he attributes this defect to overzealous attempts to prevent negative supply shocks, which are inflationary, from eroding real money balances, depressing aggregate demand, and increasing unemployment.

Taylor's assumption that the Federal Reserve has behaved as if it is greatly concerned about unemployment suggests a positive response of money growth to increases in both inflation and unemployment. But, as the table indicates, positive correlations of money growth with past inflation and past unemployment are not a persistent feature of the data either for the United States or for other economies. In fact, none of the eight large economies 


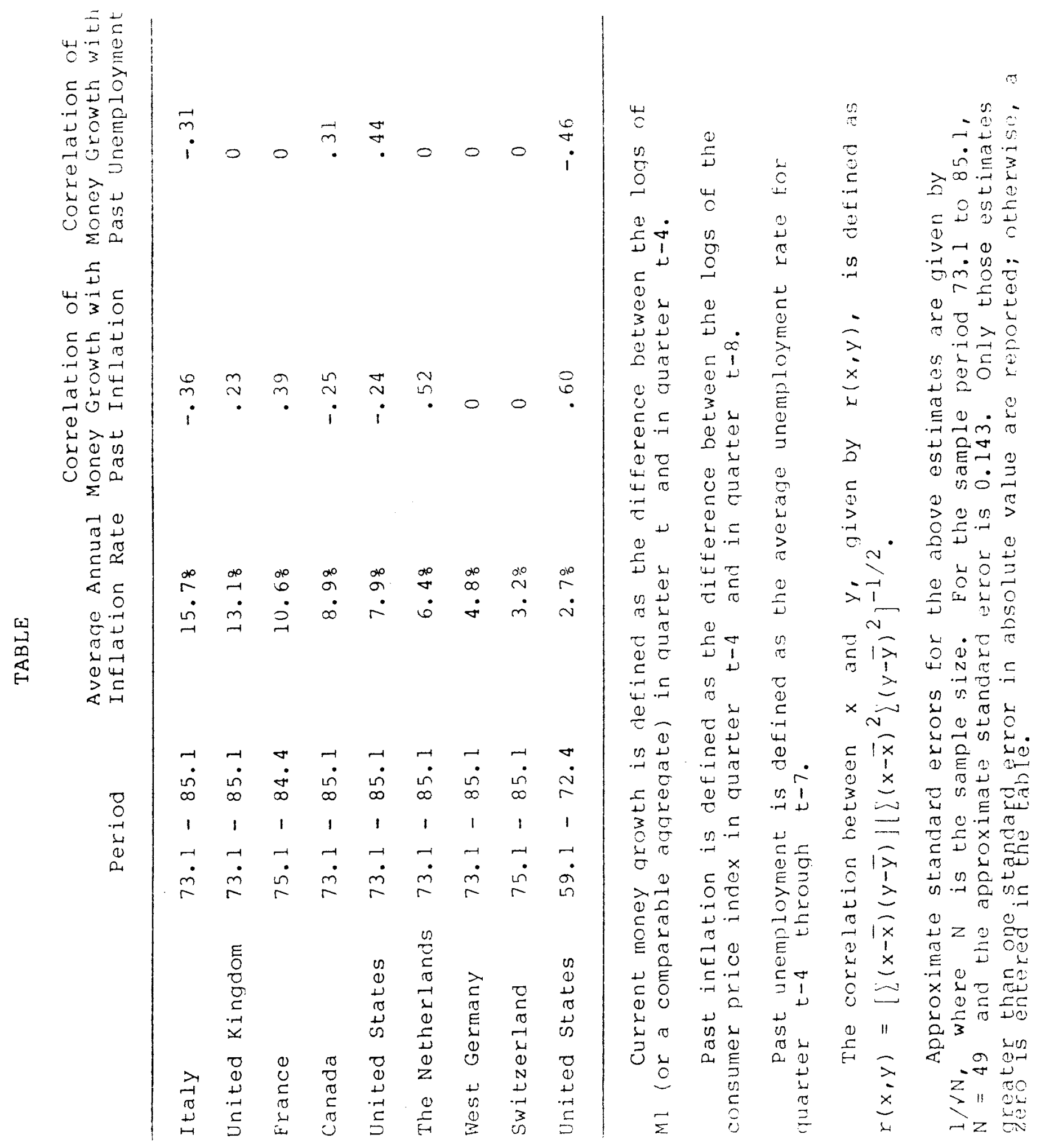


provide an example in which both of these correlations are positive. Most notably, although the sample correlation of money growth with past inflation for the United states is positive for the entire interval 1959-84, during the period 1973-85, when apparently large negative supply shocks occurred, this sample correlation was negative. Moreover, during the earlier period, 1959-72, when the correlation of money growth with past inflation was highly positive, the correlation of money growth with past unemployment was negative.

In addition, Taylor's argument that accommodation of inflation is responsible for excessive inflation suggests a positive relation between the correlation of money growth with past inflation and the average inflation rate. The table shows that money growth is positively correlated with recent past inflation in the United Kingdom and France, both of which had relatively high average inflation, and that money growth is uncorrelated with recent past inflation in West Germany and Switzerland, which were the economies with lowest average inflation. The data for other counties, however, contradict this pattern. The correlation between money growth and past inflation is positive for the United States in the earlier period and for the Netherlands, both of which had lower average inflation than the United states in the later period, and is negative for both Canada, which had higher average inflation than the United states, and Italy, which had the highest average inflation.

The international data also show a similar absence of a clear relation between average inflation and the responsiveness of money growth to past unemployment. Canada is the only economy, besides the United States for the later period, for which money growth is positively correlated with past unemployment. In Italy, the highest inflation economy, this correlation is negative. It is also worth noting that the patterns of correlation of money growth with past growth rates of aggregate output show a similar absence of any clear relation to 
average inflation. These findings imply that neither the positive correlations of money growth with past inflation in France, the United Kingdom, and the Netherlands nor the high average inflation in Italy, France, and the United Kingdom is a consequence of zealous concern for stabilizing unemployment (or output growth).

Another problem with Taylor's argument is that it leads to the question of why the Federal Reserve has persistently followed an inefficient policy. Taylor suggests "that at least until recently, the superiority of the less-accommodative policy has not generally been realized or believed" (1982, p. 84). This explanation accords with standard monetarist criticisms of Federal Reserve policy, perhaps best exemplified in the historical research of Friedman and Schwartz (1963), that attribute bad monetary policy to idiosyncratic shortcomings of the monetary authorities, especially ignorance and perhaps also cowardice. A complementary line of historical analysis argues that bad policy results from perverse bureaucratic incentives-see, for example, Toma $(1982,1985)$. Both of these theories of excessive inflation imply that the solution to the alleged problem of inefficient accommodation of inflation is the promulgation of laws that effectively constrain the monetary authority to pursue efficient policies. A difficulty with these theories as positive economics is that they provide no explanation for the absence of such apparently desirable laws, beyond the implication that the basic problem is that the higher political authorities and the public are unenlightened.

Another theory that emphasizes concern about unemployment, developed in the work of Kydland and Prescott (1977) and Barro and Gordon (August 1983), focuses on assumed incentives for the monetary authority to produce unanticipated inflation and attributes inefficient monetary policy to the consequent timeinconsistency of efficient monetary policy. Barro and Gordon suggest that negative productivity innovations that 
contemporaneously increase both unemployment and inflation also increase the incentive for the Federal Reserve to try to produce unanticipated inflation, with the result of higher money growth and inflation in subsequent periods. But, as we have seen, no pattern of persistently positive correlations of money growth with past inflation and past unemployment is evident in the data.

The analysis that follows identifies factors that are unrelated to stabilization objectives and average inflation and that provide a general explanation for correlations of money growth with past inflation and past unemployment and for international differences in these correlations. This analysis focuses on hypothetical differences in the sample variances of disturbances to productivity growth and to aggregate demand. To sharpen this focus, the analysis assumes that the only objective for monetary policy is the achievement of a given target time path for inflation. Importantly, the analysis abstracts from perversity or stupidity on the part of monetary authorities or the public and from time-consistency problems associated with incentives to produce unanticipated inflation.

\section{Analytical Framework}

Consider the following setup, which, although simple, is quite general and includes as special cases the essential properties of several well known models. The key assumptions about the proximate determination of wages and employment are the setting of the nominal wage rate in period $t$ equal to the rational expectation of its market-clearing level conditional on information available in period $t-i$,

$$
\text { (1) } \quad W_{t}=E_{t-i} W_{t}^{*} \quad i=0,1,2, \ldots
$$

the production function relating output to employment of labor services and to other factors, 
(2)

$$
Y_{t}=\alpha N_{t}+Z_{t^{\prime}} \quad 0<\alpha<1
$$

and the setting of employment and output to equate the marginal product of labor services to the real wage rate,

$$
N_{t}=(1-\alpha)^{-1}\left(P_{t}-W_{t}+\ln \alpha+z_{t}\right),
$$

where

$$
\begin{aligned}
& w_{t} \quad \begin{array}{l}
\text { is the log of the nominal wage rate in } \\
\text { period } t,
\end{array} \\
& W_{t}^{*} \text { is the log of the nominal wage rate that would } \\
& \text { be consistent with clearing the labor market in } \\
& \text { period } t,
\end{aligned}
$$

$Y_{t}$ is the log of output in period $t$,

$\mathrm{N}_{t}$ is the log of employment of labor services in period $t$,

$z_{t} \quad$ measures the total effect of exogenous stochastic variables that influence labor productivity in period $t$, and $\mathrm{P}_{t} \quad$ is the $\log$ of the output price level in period t.

The results reported by Nelson and Plosser (1982) suggest the specification that the growth rate of productivity, $\Delta z_{t}$, is the sum of a permanent component, $g_{t}$, assumed to be a random walk with innovation $\varepsilon_{t}$, and a transitory component, $z_{t}$ ' assumed to be a white noise - that is,

$$
\Delta z_{t}=g_{t}+z_{t}=g_{t-1}+\varepsilon_{t}+z_{t}
$$

where $\varepsilon_{t}$ and $z_{t}$ have zero means and stationary variances $V(\varepsilon)$ and $V(z)$ and are uncorrelated serially and with other random variables. 
The analysis assumes that the monetary authority revises policy at a regular interval. In this framework, this decisionmaking interval defines the length of a period. Thus, monetary policy in period $t$ is based on information available in period $t-1$.

Within this framework, three special cases of equation (1), which differ according to the value of the parameter $i$, are worth noting:

(a) If $i$ equals zero, the nominal wage rate responds to current information. In this case, forecast errors made by private agents play no role. Actual employment always equals the supply of labor services and changes in employment and output correspond to changes in labor supply and productivity.

(b) If $i$ equals unity, the nominal wage rate is predetermined, but wage setting and policy making are synchronized. In this case, given that employment adjusts to equate the marginal product and the real wage rate, unanticipated realizations of either output price or productivity can cause actual employment to differ from the supply of labor services. Nevertheless, because, with $i$ equal to unity, the monetary authority has no informational advantage, monetary policy does not systematically affect employment and output. [Although this model focuses on the unpredictability of labor demand, rather than on incomplete contemporaneous information, the main implications in this case are isomorphic to those of the classic equilibrium monetary business cycle models--for example, Lucas (1973) and Barro (1976).]

(c) If i equals two or more, not only is the nominal wage rate predetermined, but the monetary authority also reacts to new information more frequently than nominal wages are adjusted. [The seminal paper by Fischer (1977), integrating rational expectations into a Keynesian framework, analyzed this case.] This informational advantage means that the monetary authority's 
systematic policy of controlling inflation can have side effects on unemployment. The analysis that follows uses this case. For simplicity, it assumes that i equals two.

The first step in analyzing the implications of equations (1) - (3) is to determine the market-clearing wage rate by substituting the supply of labor services, denoted $\mathrm{N}^{*}$, for $\mathrm{N}_{t}$ in equation (3) and solving for

(5) $\quad W_{t}^{*}=P_{t}+\ln \alpha+z_{t}-(1-\alpha) N^{*}$.

For simplicity, the analysis treats labor supply as constant. The next step is to determine the actual nominal wage rate by applying the operator $E_{t-2}$ to equation (5) and substituting into equation (1) to get

$$
w_{t}=E_{t-2} P_{t}+\ln \alpha+E_{t-2} Z_{t}-(1-\alpha) N^{*}
$$

To determine employment substitute equation (6) into equation ( 3 ), which yields

$$
N_{t}-N^{*}=(1-\alpha)^{-1}\left(P_{t}-E_{t-2} P_{t}+z_{t}-E_{t-2} Z_{t}\right)
$$

Equation (7) indicates that the difference between actual employment and labor supply is proportionate to the sum of wage setters' forecast errors for the output price level and for productivity. Specifically, positive forecast errors for output price and productivity cause excess employment. The forecast error in productivity reflects exogenous innovations in the components of $\Delta z_{t}$. The forecast error in output price remains to be analyzed. Finally, to determine unemployment, define $\mathrm{u}_{t}$ to be the deviation in the log of unemployment from a constant (equilibrium) level associated with equality between $\mathrm{N}_{\mathrm{t}}$ and $\mathrm{N}^{*}$, and assume that 


$$
U_{t}=-\left(N_{t}-N^{*}\right)
$$

The remaining elements in specifying the behavior of private agents are the assumption that output price adjusts each period to equate actual output and output demand, and a general specification of output demand,

$$
Y_{t}=k\left(M_{t}-P_{t}\right)+x_{t}, k>1
$$

where $M_{t}$ is the $\log$ of a nominal monetary aggregate in period $t$ and $x_{t}$ measures the total effect of other variables that influence output demand. For simplicity, the analysis assumes that $k$ equals unity. This assumption means that the analysis abstracts from induced, as opposed to autonomous, changes in velocity and also from the effect of current productivity innovations on employment. (With $k$ equal to unity, the increase in the price level resulting from a negative productity innovation is just enough to reduce real wages in line with the reduction in the marginal product of labor services, so that employment does not change.) The analysis also assumes that the demand disturbance $x_{t}$ is the sum of a permanent component, $D_{t}$, assumed to be a random walk with innovation $e^{\prime}$ ' and a transitory component, $x_{t}$ ' assumed to be a white noise--that is,

$$
x_{t}=D_{t}+x_{t}=D_{t-1}+e_{t}+x_{t^{\prime}}
$$

where $e_{t}$ and $x_{t}$ have zero means and stationary variances $v(e)$ and $V(x)$ and are uncorrelated serially and with other random variables.

The distinctive feature of the model is the assumption that the only objective of the monetary authority in period $t-1$ is to set $M_{t}$ to achieve an exogenous target value, denoted by $\Pi_{t-1}$, for the inflation rate from period $t-1$ to period $t$. The 
assumption that the inflation target is exogenous--specifically, independent of the time series of unemployment--ensures that the inflation target is not acting as a proxy for a stabilization objective. Assume also that monetary control is precise and that the information set of private agents in period $t-1$ includes $\Pi_{t-1}$

Although monetary control is precise, because $z_{t}$ and $x_{t}$ are stochastic variables, the monetary authority in general cannot achieve its inflation target exactly. Nevertheless, it can set $M_{t}$ to equate expected inflation to the target--that is, $E_{t-1} P_{t}-P_{t-1}=\Pi_{t-l}$. Given that inflation deviates from its target value by only a white-noise forecast error, the time series properties of actual inflation suggest the specification of $\pi_{t}$ as an autoregressive process. For simplicity, however, the analysis assumes that the inflation target is constant--that is, $\Pi_{t}=\pi$ for all $t$. Accordingly, expectations about the price level are

(11) $\quad E_{t-1} P_{t}=P_{t-1}+\Pi$ and

(12) $\quad E_{t-2} P_{t}=P_{t-2}+2 \pi$.

3. Correlations of Money Growth with Past Inflation and Past Unemployment

The analysis of the model given by equations (1) through (12) involves solving for current money growth, past inflation, and past unemployment in terms of realizations of the exogenous random shocks, and using these solutions to calculate the implied covariances between current money growth and past inflation and between current money growth and past unemployment. Substituting equation (2) for $Y_{t}$ and equation (7) for $N_{t}$ into equation (9) gives 
(13)

$$
\begin{aligned}
\alpha N^{*}+\alpha(1-\alpha)^{-1}\left(P_{t}-E_{t-2} P_{t}\right. & \left.+z_{t}-E_{t-2} z_{t}\right)+z_{t} \\
& =M_{t}-P_{t}+x_{t} .
\end{aligned}
$$

Applying the operator $E_{t-1}$ to equation (13) yields, after setting $E_{t-1} M_{t}$ equal to ${ }^{M}{ }_{t}$,

$$
\begin{aligned}
M_{t}=\Pi & +P_{t-1}+E_{t-1} Z_{t}-E_{t-1} X_{t}+\alpha N^{\star} \\
& +\alpha(1-\alpha)^{-1}\left(E_{t-1} P_{t}-E_{t-2} P_{t}+E_{t-1} Z_{t}-E_{t-2} Z_{t}\right) .
\end{aligned}
$$

Equation (14) says that the monetary authority's choice of $M_{t}$ depends on the price level in period $t-1$ and on the monetary authority's inflation target, on its forecasts of productivity, output demand, and labor supply for period $t$, and on the difference between its current forecasts of prices and productivity in period $t$ and the forecasts on which nominal wages for period $t$ were based.

Substituting equation (14) for $M_{t}$ into equation (13) gives, after substituting equations (11) and (12) for $E_{t-1} P_{t}$ and $E_{t-2} P_{t}$

$$
\Delta P_{t}=I-\left(z_{t}-E_{t-1} z_{t}\right)+(1-\alpha)\left(x_{t}-E_{t-1} x_{t}\right)
$$

Equation (15) says that either a negative forecast error for productivity or a positive forecast error for demand causes inflation to exceed the monetary authority's target.

Finally, substituting equation (7) for ${ }^{N}{ }_{t}$ and equation (12) for $E_{t-2} P_{t}$ into equation (8) gives

$$
U_{t}=-(1-\alpha)^{-1}\left(\Delta P_{t}-I+\Delta P_{t-1}-I+Z_{t}-E_{t-2} Z_{t}\right)
$$


Equation (16) says that either inflation below its target or a negative forecast error for productivity cause unemployment to exceed its constant equilibrium level.

To calculate the relevant covariances for a simple, but revealing, case assume that the information set of all agents in period $t-i$ includes the permanent and transitory components of $\Delta \mathrm{Z}_{\mathrm{t}-\mathrm{i}}$ and $\mathrm{x}_{\mathrm{t}-\mathrm{i}}$. Given the stochastic processes specified by equations (4) and (9), this assumption implies that

$$
\begin{aligned}
& \Delta E_{t-1} z_{t}=g_{t-3}+\varepsilon_{t-2}+2 \varepsilon_{t-1}+z_{t-1}, \\
& \Delta E_{t-1} z_{t}-\Delta E_{t-2} z_{t}=-2 \varepsilon_{t-2}+2 \varepsilon_{t-1}-z_{t-2}+z_{t-1}, \\
& z_{t-1}-E_{t-2} z_{t-1}=\varepsilon_{t-1}+z_{t-1}, \\
& z_{t-1}-E_{t-3} z_{t-1}=2 \varepsilon_{t-2}+\varepsilon_{t-1}+z_{t-2}+z_{t-1}, \\
& E_{t-1} x_{t}-E_{t-2} x_{t-1}=e_{t-1}, a^{\prime} \\
& x_{t-1}-E_{t-2} x_{t-1}=e_{t-1}+x_{t-1} .
\end{aligned}
$$

[If, in contrast to this specification, the information set of wage setters and the monetary authority does not include the permanent and transitory components of the disturbances, then realized forecast errors would exhibit signs of positive serial correlation in a small sample that contained one or more dominant large innovations to one or both of the permanent components. The important papers by Brunner, Cukierman, and Meltzer (1980, 1983) analyze various implications of this effect, although they treat money growth as exogenous rather than, as in the present model, as derived from the objectives of the monetary authority.] 
Differencing equation (14) and backdating equations (15) and (16), after combining these equations and substituting the above expressions for the expectations and the forecast errors, yields

$$
\begin{aligned}
\Delta M_{t}=\Pi+ & g_{t-3}+(1-\alpha)^{-1} \varepsilon_{t-1}+\left[1-\alpha(1-\alpha)^{-1}\right] \varepsilon_{t-2} \\
& +x_{t-1}-\alpha\left(e_{t-2}+x_{t-2}\right) .
\end{aligned}
$$

$$
\begin{aligned}
& \Delta \mathrm{P}_{t-1}=\pi-\varepsilon_{t-1}-z_{t-1}+(1-\alpha)\left(e_{t-1}+x_{t-1}\right), \text { and } \\
& U_{t-1}=-\left[(1-\alpha)^{-1} \varepsilon_{t-2}+e_{t-1}+x_{t-1}+e_{t-2}+x_{t-2}\right] .
\end{aligned}
$$

Equations (17), (18), and (19) imply

$$
\begin{aligned}
& \operatorname{cov}\left(\Delta \mathrm{M}_{t}, \Delta \mathrm{P}_{t-1}\right)=-(1-\alpha)^{-1} \mathrm{~V}(\varepsilon)+(1-\alpha) \mathrm{V}(\mathrm{x}) \text { and } \\
& \operatorname{cov}\left(\Delta \mathrm{M}_{t}, \mathrm{U}_{t-1}\right)=(2 \alpha-1)(1-\alpha)^{-2} \mathrm{~V}(\varepsilon)+\alpha \mathrm{V}(\mathrm{e})-\mathrm{V}(\mathrm{x}) .
\end{aligned}
$$

Equations (20) and (21) express the covariances of money growth with past inflation and past unemployment as linear functions of the variances of the underlying random variables. Depending on the relative size of these underlying variances, the two covariances of interest can be positive, negative, or zero. The relations between the underlying variances and the two covariances of interest arise as follows:

A negative disturbance to productivity growth in period $t-1$ causes output growth to be low and inflation to be high in period $t-1$. If the disturbance to productivity growth is transitory, i.e., a negative realization of $z_{t-l}$, the monetary authority in period $t-1$ expects inflation to decrease to its previous rate in period $t$ without any adjustment in money growth. If, alternatively, the disturbance to productivity growth was permanent, i.e., a negative realization of $\varepsilon_{t-1}$, the 
monetary authority in period $t-1$ expects that, without any adjustment in money growth, output growth would continue to be low and inflation would continue to be high in period $t$. Accordingly, in order to achieve its inflation target, the monetary authority would decrease money growth in period $t$. In this way, permanent disturbances to productivity growth in period $t-1$ cause high inflation in period $t-1$ to be associated with low money growth in period $t$.

This reduction in money growth in period $t$, which wage setters in period $t-2$ did not anticipate, causes unemployment temporarily to be high in period $t$. The monetary authority in period $t$, consequently, expects two opposing influences on inflation in period $t+l$. The continuing low productivity growth will tend to make inflation high, whereas the recovery of employment will tend to make inflation low. Accordingly, whether or not, in order to achieve its inflation target, the monetary authority keeps money growth low in period $t+l$ depends on the size of the parameter $\alpha$. To the extent that the parameter $\alpha$ exceeds one-half, the effect of the recovery of employment dominates, and permanent disturbances to productivity growth in period $t-1$ cause high unemployment in period $t$ to be associated with high money growth in period $t+l$.

A positive disturbance to demand in period $t-1$ also causes inflation to be high in period $t-l$. If the disturbance to demand is transitory, i.e., a positive realization of $x_{t-1}$, the monetary authority in period $t-l$ expects demand to decline in period t. Accordingly, to achieve its inflation target, the monetary authority would increase money growth in period $t$. In this way, transitory disturbances to demand period $t-1$ cause high inflation in period $t-1$ to be associated with high money growth in period $t$. If, alternatively, the disturbance to demand is permanent, i.e., a positive realization of $e_{t-l}$, the monetary authority in period $t-l$ expects demand to remain 
constant and inflation to decrease to its previous rate in period $t$ without any change in money growth.

Positive disturbances to demand in period $t-1$ also cause unemployment to be low and output to be high in periods $t-1$ and $t$. Thus, transitory disturbances in demand in period $t-1$ cause low unemployment in period $t-1$ to be associated with high money growth in period $t$. The monetary authority in period $t$, however, expects unemployment to return to its normal level and output growth to be low in period $t+1$. Accordingly, the monetary authority in period $t$ expects that, without any adjustment in money growth, inflation would be high in period $t+1$. To achieve its inflation target, it would decrease money growth in period $t+l$. In this way, disturbances to demand in period $t-1$, either permanent or transitory, cause low unemployment in period $t$ to be associated with low money growth in period $t+1$. The net effect is that permanent disturbances to demand cause positive comovements of money growth and past unemployment, whereas, given that $\alpha$ is less than unity, transitory disturbances to demand cause negative comovements of money growth with past unemployment.

This analysis suggests that intertemporal and international differences in the pattern of correlation of money growth with past inflation and with past unemployment can result from international differences in the relative magnitudes of the sample variances of the underlying permanent and transitory disturbances. Equations (20) and (21) indicate that in this model the critical factor is the magnitude of transitory disturbances to demand, given by $V(x)$, relative to the magnitudes of permanent disturbances to demand and to productivity, given by $V(e)$ and $V(\varepsilon)$. Specifically, the analysis suggests that the change in the pattern of correlation in the United States from the earlier to later period results from a decrease in $\mathrm{V}(\mathrm{x})$ relative to both $\mathrm{V}(\mathrm{e})$ and $\mathrm{V}(\varepsilon)$. 
As explanations for the pattern of correlations for the other economies, assuming that $\alpha$ is about one-half, the analysis suggests that in Italy $V(x)$ was larger than $V(e)$ but smaller than four times $V(\varepsilon)$, that in the United Kingdom, France, and the Netherlands $V(x)$ was large relative to $V(\varepsilon)$ but was about the same size as $V(e)$, that in Canada, as in the United States for the later period, $V(x)$ was smaller than $V(e)$ and smaller than four times $V(\varepsilon)$, and that in Switzerland and West Germany $\mathrm{V}(\mathrm{x})$ was about equal to $\mathrm{V}(\mathrm{e})$ and also about equal to four times $V(\varepsilon)$.

\section{Summary}

International data show that the eight largest western economics exhibit a wide variety of patterns for the correlations of money growth with past inflation and past unemployment and that these patterns seem to be unrelated to average inflation. Theoretical analysis shows that a model in which the monetary authority behaves as if its sole objective is control of inflation is consistent with any pattern of correlations of money growth with past inflation and past unemployment. Moreover, this analysis suggests that intertemporal and international differences in these sample correlations result from differences in the sample variances of disturbances to productivity growth and to aggregate demand. Specifically, the analysis suggests that the critical difference between the pre-1973 and post-1973 periods for the United States was a decrease in the importance of transitory disturbances to aggregate demand relative to permanent disturbances to aggregate demand and to productivity growth.

More generally, these results imply that we cannot readily infer the objectives of the monetary authority from observed patterns of monetary policy. Specifically, the idea that monetary policy, either in the United States or in other countries, has attempted to stabilize real activity and to control unemployment may be an illusion. 


\section{REFERENCES}

R.J. Barro, "Rational Expectations and the Role of Monetary Policy," Journal of Monetary Economics, 2, January 1976; reprinted in R.J. Barro, Money, Expectations, and Business Cycles (New York: Academic Press, 1981) and in Rational Expectations and Econometric Practice, R.E. Lucas, Jr. and T.J. Sargent, eds. (Minneapolis: University of Minnesota Press, 1981).

R.J. Barro and D. B. Gordon, "A Positive Theory of Monetary Policy in a Natural Rate Model," Journal of Political Economy, 91, August 1983.

K. Brunner, A. Cukierman, and A.H. Meltzer, "Stagflation, Persistent Unemployment, and the Permanence of Economic Shocks," Journal of Monetary Economics, 6, October 1980.

K. Brunner, A. Cukierman, and A.H. Meltzer, "Money and Economic

Activity, Inventories, and Business Cycles," Journal of Monetary Economics, 11, May 1983.

S. Fischer, "Long-Term Contracts, Rational Expectations, and the Optimal Money Supply Rule," Journal of Political Economy, 85, February 1977; reprinted in Rational Expectations and Econometric Practice, R.E. Lucas, Jr. and T.J. Sargent, eds. (Minneapolis: University of Minnesota Press, 1981).

M. Friedman and A.J. Schwartz, A Monetary History of the United States, 1867-1960 (Princeton: Princeton University Press for the NBER, 1963).

F.E. Kydland and E.C. Prescott, "Rules Rather Than Discretion: The Inconsistency of Optimal Plans," Journal of Political Economy, 85, June 1977.

R.E. Lucas, Jr., "Some International Evidence on Output-Inflation Tradeoffs," American Economic Review, 63, June 1973; reprinted in R.E. Lucas, Jr. , Studies in Business-Cycle Theory (Cambridge: MIT Press, 1981).

C.R. Nelson and C.I. Plosser, "Trends and Random Walks in Macroeconomic Time Series: Some Evidence and Implications," Journal of Monetary Economics, 10, September, 1982. 
J.B. Taylor, "Stabilization, Accommodation and Monetary Rules," American Economic Review, 71, May 1981.

J.B. Taylor, "Establishing Credibility: A Rational Expectations Viewpoint," American Economic Review, 72, May 1982.

M. Toma, "Inflationary Bias of the Federal Reserve System: A Bureaucratic Perspective," Journal of Monetary Economics, 10 , September 1982.

M. Toma, "A Duopoly Theory of Government Money Production: The 1930 s and 1940s," Journal of Monetary Economics, 15, May 1985. 